\title{
Digitalizacja usług w modelu biznesowym przedsiębiorstwa uzdrowiskowego na przykładzie programu Kuracjusz
}

\section{Digitalisation of Services in the Business Model of a Spa Enterprise Based on the Example of the "Kuracjusz" Program}

Streszczenie: Zachowanie właściwych proporcji pomiędzy technologią a zarządzaniem staje się współczesnym wyzwaniem dla wielu menadżerów, zwłaszcza tych, którzy uwierzyli, że świat artefaktów jest rzeczywistością. Kształtowane w procesie zarządzania relacje z klientami, a także relacje pomiędzy pracownikami powinny determinować rozwój technologiczny, zwłaszcza w przedsiębiorstwie uzdrowiskowym. Ponadto rodzaj biznesu, kultura organizacyjna i segment klientów powinny stymulować wybór odpowiednich modeli z wykorzystaniem digitalizacji. Tylko połączenie relacji wirtualnych z relacjami bezpośrednimi może przedsiębiorstwu uzdrowiskowemu przynieść sukces. Styczność przestrzenna jako najważniejsza kategoria w naukach społecznych - jak się wydaje, nie powinna być w tym sektorze usług wyparta w całości przez internet. Celem artykułu jest wskazanie znaczenia digitalizacji w modelu biznesowym, a także ukazanie barier w jego wdrażaniu na przykładzie przedsiębiorstwa uzdrowiskowego. W artykule przedstawiono zatem przegląd stanowisk na temat modelu biznesu oraz propozycję własną modelu biznesowego, a także znaczenie digitalizacji w modelach biznesowych oraz wykorzystanie e-narzędzi na przykładzie programu Kuracjusz w uzdrowisku. Autorską propozycją jest model harmonia jako rozwiązanie pomiędzy zarządzaniem tradycyjnym opartym na relacjach bezpośrednich a zarządzaniem wirtualnym.

\begin{abstract}
The right balance between technology and management is becoming a modern challenge for many managers, especially those who believe that the world of artefacts is a reality. Relationships with clients shaped in the management process, as well as relations between employees should determine technological development, especially in a spa enterprise. In addition, the type of business, organisational culture, and customer segment should stimulate the selection of appropriate models using digitalisation. Only a combination of virtual and direct relationships can make a spa company successful. Spatial contact - as the most important category in social sciences - does not seem to be entirely crowded out over the Internet in this service sector. The aim of the article is to indicate the place of digitalisation in the business model based on the example of a spa company. The article therefore presents a review of positions on the business model, own proposition of the business model, as well as the importance of digitalisation in business models and the use of e-tools based on the example of the "Kuracjusz" program in a health resort. The proposition is the harmony model, as a solution between traditional management based on direct relations, and virtual management.
\end{abstract}


Słowa kluczowe: digitalizacja; model biznesu; przedsiębiorstwo uzdrowiskowe

Keywords: business model; digitalization; spa company

Otrzymano: 1 kwietnia 2019

Received: 1 April 2019

Zaakceptowano: 10 października 2019

Accepted: 10 October 2019

\section{Sugerowana cytacja/Suggested citation:}

Tutaj, J. (2019). Digitalizacja usług w modelu biznesowym przedsiębiorstwa uzdrowiskowego na przykładzie programu Kuracjusz. Przedsiębiorczość - Edukacja [Entrepreneurship - Education], 15(2), 171-183. doi: 10.24917/20833296.152.12

\section{Wstęp}

Wielość rzeczywistości, w których mają miejsca ludzkie działania, to konstelacja różnych układów i uporządkowań (Manterys, 1997). Gama wirtualnych kontinuów, na których można sytuować aktywność ludzką w świecie, nie wyczerpuje się w polaryzacji obiektywne - subiektywne (Manterys, 1997). Dualizm świata jest charakterystyczny dla rynku tradycyjnego, rynek wirtualny - do którego świat się zbliża - porusza się w innych kategoriach, które przedstawiano w modelu przedsiębiorstwa 3.0 - trzeciej generacji (Hołodnik, Perechuda, 2016). Przedsiębiorstwa trzeciej generacji operują w pustych polach znaczeń, koncentrują się na przepływie energii, są odsieciowane, są odpodmiotowione i opierają się na paradygmacie humanistycznym (Hołodnik, Perechuda, 2016). Zarządzanie na tym poziomie wymaga nowych umiejętności i zupełnie innej perspektywy. Obecna edukacja nie przygotowuje menadżerów do wyzwań trzeciej generacji. Dlatego w większości dalej będziemy obserwować tworzenie i ulepszanie modeli biznesowych charakterystycznych dla zarządzania firmą typu 2.0, gdzie następuje generowanie strumienia informacji, wiedzy i energii do i od klienta (Kania, 2010). Jednak już dzisiaj firmy będą musiały się uporać z nadmiarem informacji i wiedzy, ich jakością. Wskazanie konieczności i wdrażania mechanizmów redukcji nadmiarowych i niepotrzebnych informacji oraz wiedzy staje się koniecznym elementem zarządzania. Problemem współczesnych firm jest odpowiedni dobór e-narzędzi oraz właściwy balans - tylko w przedsiębiorstwach, które operują na rynku tradycyjnym i wirtualnym, pomiędzy technikami tradycyjnymi a tymi, które służą do poruszania się w świecie wirtualnym. Optymalizacja kosztów i przychodów nie jest jedynie wypadkową poziomu cyfryzacji przedsiębiorstwa. Takie czynniki, które w zarządzaniu są pomijane, jak: dobra energia, duch przedsiębiorstwa, empatia, będą odgrywać coraz większą rolę. Traktowanie przedsiębiorstwa jako świątyni wiedzy, gdzie jest tworzona, przechowywana i ulepszana mądrość, wydaje się właściwym punktem odniesienia i dostosowywania procesów digitalizacji, które planujemy zastosować w przedsiębiorstwie.

\section{Analiza definicji i wymiarów modelu biznesowego}

Jak zauważył M. Wierzbiński (2017), pojęcie modelu biznesowego w obszarze zarządzania strategicznego pojawiło się wraz z rozwojem internetu. Przedsiębiorstwa, które prowadzą działalność w przestrzeni wirtualnej, w przeciwieństwie do przedsiębiorstw prowadzących działalność w tradycyjny sposób, dzięki nowej technologii mogą zaproponować 
klientom nową ofertę, o nowych celach i nowej wartości. Digitalizacja przedsiębiorstw pozwala rozwinąć nowe modele pozyskiwania przychodów, a także zasadniczo skraca łańcuch dystrybucji i promocji. Zdaniem M. Wierzbińskiego, definiując model biznesowy, należy przede wszystkim odwołać się do jego pierwszych definicji, w tym definicji P. Timmersa (Timmers, 1998), który model biznesowy rozumiał jako:

- „architekturę produktu, usług i przepływu informacji z uwzględnieniem charakterystyki różnych aktorów biznesowych i ich ról,

- charakterystykę potencjalnych korzyści osiąganych przez różnych aktorów biznesowych,

- charakterystykę źródeł przychodów.

P. Timmers uznał, że podstawą do określenia architektury modelu biznesu jest przeprowadzenie analizy łańcucha wartości. W szczególności łańcuch ten powinien zostać poddany dekompozycji, która umożliwia analizę przepływu informacji, a następnie powinien on zostać poddany rekonstrukcji” (Wierzbiński, 2017: 172).

Modelami biznesowymi przedsiębiorstw, które działają w przestrzeni internetowej, zajmowali się także P. Weill i M.R. Vitale. Odnosili się oni do roli konsumentów, klientów, partnerów biznesowych oraz dostawców, a także do łączących ich relacji, które decydują o przepływie produktów, informacji i środków pieniężnych oraz głównych korzyści do interesariuszy (Weill, Vitale, 2001). Zdaniem, P. Weilla i M.R. Vitale'a, model biznesowy składa się z trzech elementów. Pierwszym z nich są podmioty wchodzące w określone relacje biznesowe, $\mathrm{w}$ tym klienci, kooperanci i dostawcy przedsiębiorstwa. Drugim elementem są przepływy produktów, informacji i środków pieniężnych, a trzecim - „korzyści osiągane przez poszczególne podmioty wchodzące w skład modelu biznesowego, w tym przychody ze sprzedaży" (Wierzbiński, 2015: 483).

Jak zaznacza Wierzbiński, początkowe definicje modeli biznesowych, oparte na analizie sposobu działania przedsiębiorstw internetowych, akcentowały sposób osiągania przychodów ze sprzedaży, a nie zysk. Wynikało to z faktu, że tego typu firmy rzadko odnotowywały zysk. Do podstawowych modeli osiągania przychodów Wierzbiński zalicza: „model oparty na reklamach, model aukcyjny, model subskrypcyjny, model freemium (podstawowe usługi są bezpłatne, a dodatkowe mogą być płatne), model razor-and-blade (cena jednej usługi jest niska, bliska kosztom jednostkowym, podczas gdy zasadnicza część zysku jest generowana na usługach/produktach komplementarnych); model opłaty za korzystanie z usług/produktów bez ich zakupu na własność" (Wierzbiński, 2015: 483).

J. Magrett (2002) opierała model biznesowy na tworzeniu wartości dla klienta. Badaczka uznawała, że model biznesowy to opowieść, która odpowiada na następujące pytania: W jaki sposób jest tworzona wartość dla klienta? W jaki sposób przedsiębiorstwo generuje zysk? W jaki sposób przedsiębiorstwo dostarcza wartość klientom po uzasadnionych kosztach? Z kolei A. Afuah (2004) wskazywała na inne pytania ważne dla przedsiębiorstw: Jakie działania przedsiębiorstwo zamierza wykonywać? W jaki sposób wybrane działania mają być wykonywane? Kiedy wybrane działania mają być wykonywane? Dla K. Obłoja (2013) model biznesowy wiąże się z takimi pytaniami, jak: Jakie zasoby są niezbędne firmie na danym terytorium? Jakie umiejętności są potrzebne? W jaki sposób zasoby i kompetencje powinny być skonfigurowane w praktyce, czyli jaki jest łańcuch wartości? (Wierzbiński, 2015). 
Sześć podstawowych modeli funkcjonujących w praktyce polskich organizacji gospodarczych wyróżnili autorzy artykułu Modele biznesu polskich przedsiębiorstw (Gołębiowski i in., 2008). Modele te to:

a) tradycjonalista, w którym źródłem wartości dla klientów są korzyści materialne oraz relacja korzyści do ponoszonych kosztów. W ramach długiego łańcucha wartości nie występują unikatowe zasoby i kompetencje - model jest skuteczny w przypadku dużych firm o ugruntowanej pozycji rynkowej;

b) gracz rynkowy, w którym źródłem wartości dla klientów są korzyści materialne i emocjonalne. W łańcuchu wartości akcent pada na projektowanie, wytwarzanie oraz marketing i sprzedaż, przy jednoczesnym pełnieniu funkcji koordynatora łańcucha wartości - model skuteczny przy możliwości stworzenia przewagi konkurencyjnej na podstawie posiadanych zasobów oraz z tytułu korzyści skali;

c) zleceniobiorca, w którym źródłem wartości dla klientów są korzyści materialne oraz atrakcyjna relacja korzyści do ponoszonych kosztów. Łańcuch wartości jest krótki, a w jego ramach następuje koncentracja na wytwarzaniu dóbr lub świadczeniu usług na zlecenie. Model ten jest skuteczny w przypadku ograniczonego potencjału konkurencyjnego przy możliwości umacniania posiadanych kompetencji i utrzymania przewagi kosztowej;

d) specjalista, w którym źródłem wartości dla klientów są korzyści materialne i emocjonalne. Łańcuch wartości jest krótki, a w jego ramach następuje koncentracja na projektowaniu oraz marketingu i sprzedaży, przy pełnieniu funkcji koordynatora procesu wytwarzania dóbr i świadczenia usług - model jest skuteczny w sytuacji opanowania unikatowych czynników sukcesu;

e) dystrybutor, w którym źródłem wartości dla klientów są korzyści materialne oraz zadowalająca relacja korzyści do ponoszonych kosztów. W ramach krótkiego łańcucha wartości (koncentracja na sprzedaży) występują unikatowe zasoby i kompetencje w postaci wiedzy na temat rynku - głównym źródłem przychodów jest pośrednictwo handlowe;

f) integrator, w którym źródłem wartości dla klientów są korzyści materialne i emocjonalne oraz dobre relacje. W łańcuchu wartości występuje koncentracja na projektowaniu oraz marketingu i sprzedaży, przy jednoczesnym pozostaniu koordynatorem procesu tworzenia wartości dla ostatecznego użytkownika - model skuteczny w przypadku stworzenia przewagi (Nęcki, 2013: 30).

Według A. Osterwaldera, model biznesowy składa się dziewięciu elementów. Są to: segmenty klienta, propozycja wartości, kanały, relacje z klientami, strumienie przychodów, kluczowe zasoby, kluczowe działania oraz kluczowi partnerzy. Szczególne miejsce w modelu biznesowym Osterwaldera zajmuje propozycja wartości jako zestaw elementów, które mogą przyczyniać się do generowania wartości dla klienta. Można do niej zaliczyć:

- nowość - zaspokojenie nowych potrzeb, z których klienci nie zdawali sobie sprawy np. fundusze etycznego inwestowania;

- wydajność - poprawa jakości produktu lub skuteczności to tradycyjny sposób generowania wartości. Rozwiązanie to znajduje zastosowanie w sektorze komputerów osobistych - szybsze, pojemne;

- dostosowanie do indywidualnych potrzeb danego klienta - marketing indywidualny; 
- skuteczność - źródłem wartości może być po prostu to, że produkt czy usługa wspomoże klienta w wykonaniu określonego zadania;

- projekt - istotny, choć mało wymierny aspekt produktu czy usługi. Produkt może wyróżniać się z uwagi na doskonały projekt, co jest bardzo ważne np. w branży mody czy konsumenckiego sprzętu elektronicznego;

- marka i status - źródłem wartości dla konsumenta może być już sam fakt korzystania z określonej marki lub posługiwania się nią. Na przykład noszenie zegarków marki Rolex świadczy - dla niektórych - o wysokim statusie majątkowym, jazda autem marki mercedes korzystnie wpływa na samopoczucie niektórych klientów;

- wiedza - wynalazki, patenty, kwalifikacje i doświadczenie kadry;

- cena - oferowanie tej samej wartości po niższej cenie to dość powszechny sposób zaspokojenia potrzeb segmentów rynku wrażliwych na cenę - Ryanair, darmowe gazety - konieczność masowości pasażerów, reklamodawcy;

- niższe koszty - ważnym sposobem generowania wartości może być stworzenie klientom możliwości obniżania kosztów działalności - np. Salesforce oferuje swoim odbiorcom hostowaną aplikację do zarządzania relacjami z klientami. Dzięki temu nabywcy nie muszą ponosić wydatków związanych z zakupem, instalacją i utrzymywaniem oprogramowania we własnym zakresie;

- dostępność - stworzenie dostępu do produktów tym klientom, którzy wcześniej nie mogli z nich korzystać. Przykładem jest poszerzenie dostępu do oferty własności częściowej samolotów odrzutowych - przez firmę Net.Jets;

- wygoda i użyteczność - większa wygoda lub większa łatwość użytkowania może pozytywnie przekładać się na wartość danego rozwiązania dla klienta. Przykładowo, wprowadzając na rynek iPoda i uruchamiając iTunes, Apple zaoferował klientom niespotykaną dotąd wygodę poszukiwania, kupowania, pobierania i słuchania muzyki cyfrowej. Dzięki temu firmie udało się zdominować rynek (Osterwalder, 2012).

\section{Model biznesowy w przedsiębiorstwie uzdrowiskowym}

Modele biznesowe, które funkcjonują w polskich przedsiębiorstwach uzdrowiskowych, są charakterystyczne dla przedsiębiorstw drugiej generacji, zakorzenionej w społeczeństwie trzeciej fali, w erze digitalizacji, wiedzy i sieciowego „zagęszczania” (Hołodnik, Perechuda, 2016). Są to najczęściej modele biznesowe kształtowane egzogenicznie przez otoczenie: kopiowanie konkurencji (również spoza sektora) oraz wymogi klienta zarówno komercyjnego, jak i opłacanego przez NFZ. Zdaniem autora, zarządzanie przedsiębiorstwem uzdrowiskowym zdeterminowane jest sposobem zdobywania przychodów. Ponad 90\% przedsiębiorstw w Polsce opłacanych jest przez NFZ i ZUS (GUS: Klienci uzdrowisk, 2016). Przedsiębiorstwa uzdrowiskowe uczestniczą w łańcuchu redystrybucji środków budżetowych i są w moim przekonaniu quazi jednostkami budżetowymi. Dlatego zauważyć należy dużo wolniejszy, niż w innych sektorach proces urynkowienia się branży, a w tym procesów digitalizacyjnych. Celem dla zarządzających przedsiębiorstwem uzdrowiskowym jest zdobycie, powiększenie lub utrzymanie kontraktów z NFZ i ZUS-em. Klient nie jest najważniejszym wyzwaniem dla zarządzających, mimo tworzonych misji, wizji i sloganów marketingowych. Co prawda NFZ i ZUS wskazują na wymogi, w imieniu klienta, ale jednak poprzez własne kryteria, poprzez własną politykę. Ponadto przedsiębiorstwie systematycznie zwiększają procentowy udział klientów komercyjnych 
w puli swoich przychodów. W Polsce funkcjonują również przedsiębiorstwa uzdrowiskowe, gdzie w 100 \% klient jest komercyjny (najczęściej prywatne), jednak ich udział w rynku nie przekracza 16\% (GUS: Klienci uzdrowisk, 2016). Zarządzanie przedsiębiorstwem uzdrowiskowym zdeterminowane jest czteroma głównymi czynnikami: państwowym płatnikiem (NFZ, ZUS), rzeczywistymi klientami (którymi stali się - upodmiotowili się - klienci opłacani oraz klienci komercyjni), grupami zawodowymi (zwłaszcza biały personel - lekarze, związki) oraz polityką właściciela. Politykę właściciela wymieniam na czwartym miejscu nieprzypadkowo. Rola przedsiębiorstw uzdrowiskowych dla właściciela (w $84 \%$ jest to skarb państwa, samorząd), to jedno z wielu zadań, któremu nie poświęca się należytej uwagi i znaczenia. Determinanty funkcjonujące w przedsiębiorstwie uzdrowiskowym w Polsce na początku XXI w. to:

- biały personel,

- Narodowy Fundusz Zdrowia,

- polityka państwa, regionu,

- interesy właściciela,

- klient.

Nieprzypadkowo klient występuje na końcu, gdyż jest to zgodne z wieloma badaniami satysfakcji klienta w przedsiębiorstwach uzdrowiskowych (Czaja i in., 2018). Informacje i wiedza stają się naczelnym paradygmatem ich sukcesu rynkowego: klient chce wiedzieć coraz więcej o produktach i usługach, co powoduje powstanie szeregu usług digitalnych (internetowych) zarówno o charakterze informacyjnym, jak i procesowo-serwisowym (Hołodnik, Perechuda, 2016). Brzóska proponuje, by model biznesowy rozumieć jako przyjętą przez organizację metodę powiększania i wykorzystywania zasobów, w celu przedstawienia klientom oferty produktów i usług, której wartość przewyższa ofertę konkurencji i która zapewnia organizacji dochodowość (Iwasieczko, 2014). W związku z tym autorska propozycja modelu biznesowego dla przedsiębiorstwa uzdrowiskowego opiera się na przesunięciu przychodów wyłącznie na klienta komercyjnego. Proponuję zatem następujący model dla biznesu uzdrowiskowego, gdzie RPK to rozwiązywanie problemów klienta, a wektor PWUM to procesy wirtualizacji usług medycznych (rycina 1).

\section{Potencjał digitalizacji w modelach biznesowych}

W zderzeniu z wyzwaniami digitalizacji firmy można podzielić w pewnym uproszczeniu na te, które już stoją przed agresywną presją reagowania na wyzwania digitalizacji (np. bankowość, motoryzacja, transport), oraz te, które widzą już na horyzoncie digitalną transformację w swojej branży. Nie odczuwają jeszcze bezpośredniej presji, aby coś przedsięwziąć. Niezależnie jednak od tego, czy firmy już intensywnie działają, czy dopiero przymierzają się do działań, w centrum swojej uwagi stawiają technologie.

Na podstawie obserwacji do czynników determinujących przedsięwzięcia digitalizacyjne należy zaliczyć:

- wielkość, złożoność organizacji - im większa, bardziej skomplikowana struktura, tym większy wymóg używania e-narzędzi do zarzadzania,

- bezpośredni kontakt z klientem - im mniejsza odległość, tym większa presja na wprowadzenie rozwiązań internetowych,

- poziom świadomości wśród właścicieli, zarządzających oraz pracowników,

- możliwości finansowe organizacji, 
Rycina 1. Model biznesu uzdrowiska

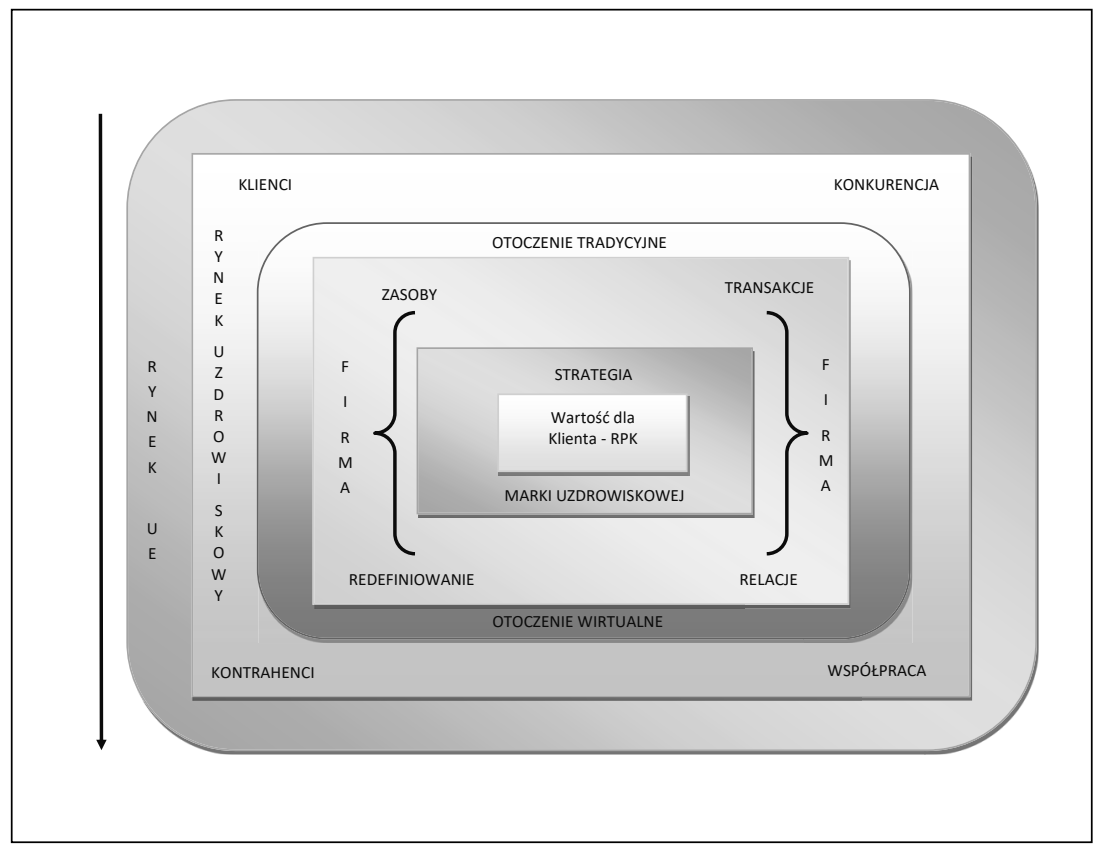

Źródło: opracowanie własne

Rycina 2. Poziom digitalizacji i nasycenia IT wg wielkości firmy

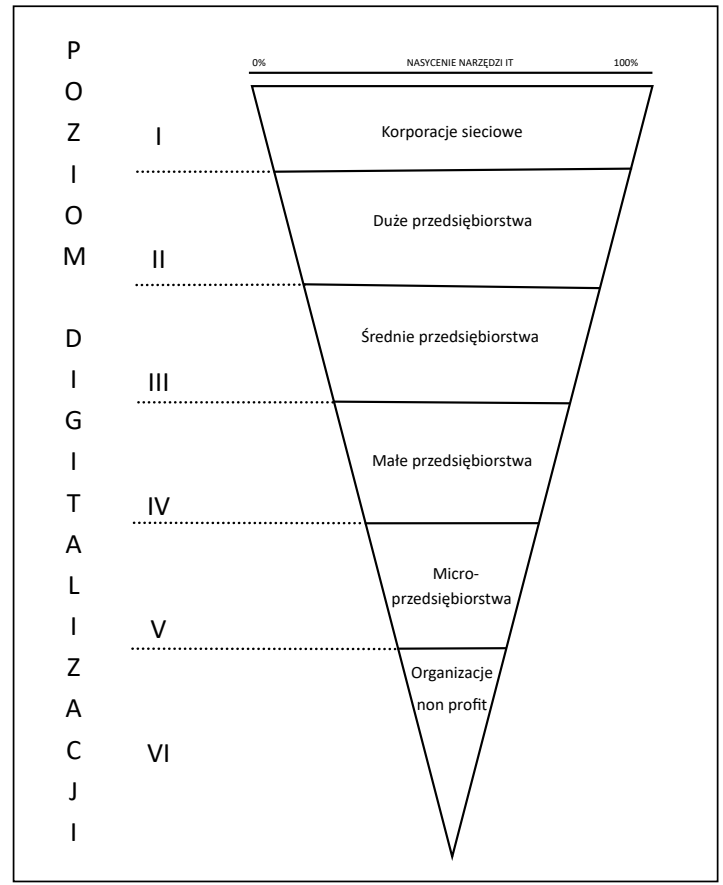

Źródło: opracowanie własne 
Rycina 3. Pole manewru na rynku tradycyjnym

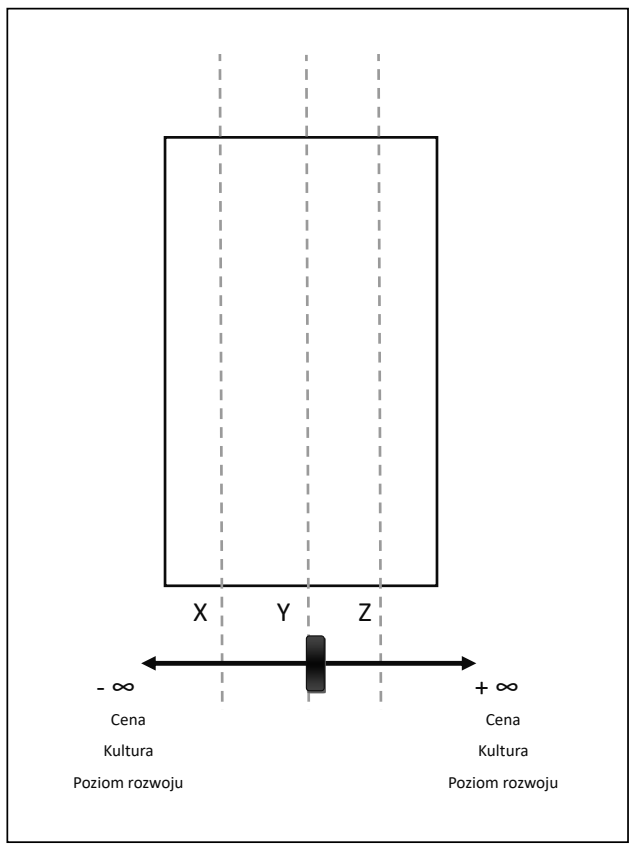

Źródło: opracowanie własne

Rycina 4. Pole manewru na rynku wirtualnym

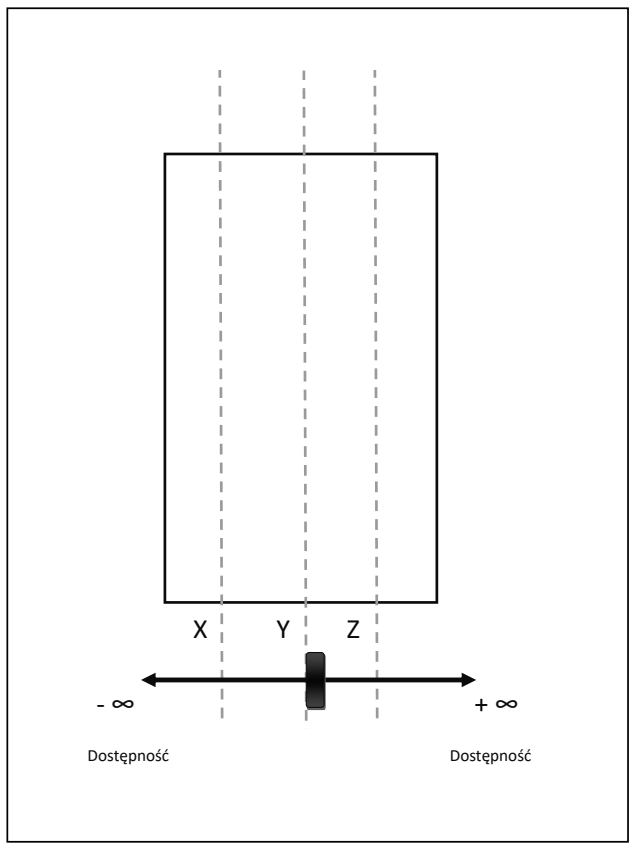

Źródło: opracowanie własne 
- udział w sieciach powiązań,

- optymalizacja kosztów i przychodów.

Wiele firm uważa, że transformacja digitalna powinna oznaczać dla nich: tworzenie produktów lub usług z wykorzystaniem innowacji technologicznych, zamianę dokumentacji papierowej na dokumentację cyfrową, rozwój mediów społecznościowych. Niektóre z tych kierunków z pewnością powinny być również elementem transformacji digitalnej, co podkreśla B. Iwasieczko - warto przypomnieć, że udana transformacja digitalna to całościowy, znacznie szerszy proces (Iwasieczko, 2014). Dlatego dziwi w przypadku wielu firm tak radykalna zmiana i przejście wyłącznie do świata wirtualnego. Takim przykładem może być firma Vitagenum z Lublina, która w pierwszej fazie rozpoczęła sprzedaż swojego produktu: badania DNA klienta i przygotowywanie na tej podstawie raportu z zaleceniami lekarskimi tylko przez strony WWW. Okazało się, że przychody w pierwszym okresie były znacznie poniżej oczekiwań i obecnie firma stosuje również tradycyjne metody sprzedaży, nawiązując relacje $\mathrm{z}$ farmaceutami, lekarzami, przychodniami, szpitalami, uzdrowiskowymi, co przynosi dobry efekt sprzedażowy.

W modelu biznesowym należy zwrócić uwagę na dobór e-narzędzi. Optymalne wykorzystanie przestrzeni wirtualnej związane jest $\mathrm{z}$ kilkoma problemami. Należy do nich tzw. próg tolerancji klienta oraz granica akceptacji.

Brak e-narzędzi może wpływać na odrzucenia danej oferty i przejście do konkurencji. Próg tolerancji łączy się również z odwrotnym zjawiskiem - swoistego zamknięcia oferty dla klienta poza jego dostępem. Ograniczenie się zatem jedynie do przestrzeni wirtualnej albo niewłaściwy wybór e-narzędzia może decydować o braku łączności z klientami, a co za tym idzie - o realizacji planów sprzedażowych. Czynnikami wpływającym na kształtowanie się takiego progu są: czas, wiek, poziom wykształcenia, zawód, osobowość klienta, a także poziom rozwoju wirtualnego otoczenia.

Innym problemem jest obszar standardu obsługi klienta, gdzie występuje granica akceptacji, której cechą jest elastyczność. Granica ta inaczej funkcjonuje w na rynku tradycyjnym i rynku wirtualnym. Na rynku tradycyjnym może przesuwać się w zależności od ceny produktu/usługi, kultury, poziomu rozwoju, natężenia potrzeby u klienta. W przypadku rynku wirtualnego najważniejszym czynnikiem będzie dostępność. Poniższe zależności przedstawiają ryciny 3 i 4 .

Program Kuracjusz jako przykład digitalizacji procesu zarządzania w przedsiębiorstwie uzdrowiskowym

Znaczna część - ponad 60\% - wszystkich przedsiębiorstw uzdrowiskowych w Polsce $\mathrm{w}$ procesie zarządzania posługuje się od kilku lat programem Kuracjusz, który powstał z myślą o sanatoriach, zakładach leczniczych, ośrodkach zabiegowych i innych placówkach, prowadzących ewidencję pacjentów i układających plany zabiegów lub zajęć. Program ten, w założeniu, gwarantuje bezpieczny i kompleksowy sposób ewidencji kuracjuszy i planowania zabiegów. Ma on wiele przydatnych funkcji i rozszerzeń potrzebnych do wspomagania działalności ośrodków rehabilitacyjnych, a w szczególności: ewidencję kuracjuszy wraz z danymi osobowymi i przynależnością do sanatoriów i kontraktów, automatyczne planowanie i rejestrowanie zabiegów wykonywanych dla określonych pacjentów, generator raportów, przyjazny i łatwy w obsłudze interfejs użytkownika, kontrolę obsadzenia kabin i sal zabiegowych, możliwość szybkiego planowania zabiegów 
z uwzględnieniem preferencji pacjenta (np. przerwa śniadaniowa, obiadowa, określony lekarz) oraz zaleceń lekarza (wymuszona kolejność, częstotliwość zabiegów), możliwość wystawiania rachunków za wykonane zabiegi, możliwość szybkiej zmiany planu zabiegów i planowania dodatkowych, drukowanie kilku rodzajów planów zabiegów, synchronizację danych z Systemem Rozliczeń Uzdrowisk ${ }^{1}$. Program Kuracjusz jest szeroko wybieranym systemem informatycznym przez przedsiębiorstwa uzdrowiskowe. Oprogramowanie sprawdza się zarówno w niewielkich instalacjach (kilka komputerów), jak i bardzo dużych wdrożeniach obejmujących kilkadziesiąt obiektów, setki komputerów, urządzeń i użytkowników. Oparty jest na skalowalnej bazie danych MS SQL Server, pozwala usprawnić pracę podmiotów zajmujących się rehabilitacją lub leczeniem sanatoryjnym, ponieważ obejmuje praktycznie całość obsługi klientów niezależnie od segmentu czy profilu leczenia.

Program Kuracjusz wyczerpuje większość potrzeb zgłaszanych przez przedsiębiorstwa uzdrowiskowe. Jednak to jedna strona medalu. Jak wygląda wdrażanie, wykorzystywanie przedstawionych możliwości w samym przedsiębiorstwie? Jak twierdzą pracownicy firmy, która stworzyła program i serwisuje jego funkcjonowanie, tylko w 35\% - średnio - przedsiębiorstwa wykorzystują możliwości programu. Wynika to przede wszystkim ze słabości działów IT i ogólnie słabego przygotowania menedżerów do procesów digitalizacyjnych. Na podstawie własnych obserwacji w kilkunastu przedsiębiorstwach należy zwrócić uwagę na bardzo słabe umiejętności informatyczne kadry. W firmie, gdzie są wprowadzone e-narzędzia, powinny zmieniać się nie tylko procesy, rozwiązania, ale cały sposób jej funkcjonowania, a zatem - zarządzania. Wyzwania digitalnej transformacji wymagają innego zarządzania niż dotychczasowe w wielu firmach. Konkurencyjność firm digitalnych opiera się m.in. na tym, która spośród nich będzie miała większą trafność w rozpoznawaniu trendów i potrzeb klientów, która lepiej wykorzysta nowe technologie, która będzie bardziej innowacyjna i szybsza, która rozwinie skuteczniejsze modele biznesowe. A to stawia konkretne wymagania wobec pracowników, nazywanych digitalnymi - sprawczymi. Wzrastająca kompleksowość działania wymaga połączenia coraz bardziej rozproszonej wiedzy pomiędzy wieloma osobami. To m.in. wpływa na konieczność wysokiej gotowości i umiejętności współpracy pracowników ponad silosami. Innowacyjność pociąga za sobą potrzebę dużego potencjału kreatywności pracowników, szybkość i zwinność wymaga umiejętności radzenia sobie ze zmianą, nieprzewidywalnością. To tylko niektóre rysy pracownika digitalnego - sprawczego, ale najważniejszą jego cechą powinno być właśnie „sprawianie”, czyli zdolność do wpływania na rzeczywistość organizacyjną firmy oraz na to, co firma oferuje na rynku. Aby pracownicy w taki sposób mogli funkcjonować, muszą mieć nie tylko odpowiednią wolę i umiejętności, ale przede wszystkim warunki, które temu sprzyjają, za co odpowiadają menedżerowie. Menedżer, który zarządza w sposób inwazyjny, posługuje się technikami, narzędziami i korzysta jedynie z przywileju swojej formalnej władzy, nigdy tego nie osiągnie. A jeżeli takich menedżerów w organizacji jest wielu, to nigdy nie osiągnie się sprawczości pracowników. Bez sprawczości pracowników sami zarządzający nie przeprowadzą firmy przez proces transformacji digitalnej. To podejście do zarządzania powinno być oparte na zupełnie innych stosunkach społecznych. Menedżer z roli zleceniodawcy przesuwa się do roli zleceniobiorcy dla pracowników. Jego główną funkcją jest inspirowanie pracowników i umożliwianie

\footnotetext{
${ }^{1}$ Informacja na temat programu Kuracjusz otrzymana od Spółki Uzdrowisko Lądek-Długopole.
} 
im działania. Cytując czołowego teoretyka i praktyka zarządzania z obszaru niemieckojęzycznego, dr. R. Sprengera: „Potrzebujemy menedżerów otwierających przestrzeń, a nie ją wypełniających" (Das ganze Konzept..., 2018).

\section{Zakończenie}

Organizacje gospodarcze powinny być elastyczne i nastawione na adaptacyjność rozwiązań nowoczesnych technologii. Model biznesowy, proces digitalizacji powinien być podporządkowany strategii organizacji. Naczelną zasadą winna być harmonia pomiędzy wykorzystywanymi technikami a metodami zarządzania. Przedsiębiorstwa uzdrowiskowe są skazane na funkcjonowanie na rynku tradycyjnym i wirtualnym. Należy podkreślić ogromną rolę wprowadzanych rozwiązań informatycznych, właściwie w każdym obszarze funkcjonowania przedsiębiorstwa uzdrowiskowego. Ma to wpływ nie tylko na poszerzenie bazy klientów, lecz także na podniesienie poziomu ich obsługi, a także na zwiększenie relacji między organizacją a klientem. Jednak wprowadzanie digitalizacji do modelu biznesowego napotyka bariery przede wszystkim w warstwie świadomości istnienia różnorodnych możliwości informatycznych oraz samych umiejętności informatycznych zarówno u kadry zarządzającej, jak i u pracowników przedsiębiorstw uzdrowiskowych.

Literatura

References

Afuah, A. (2004). Business Models. A Strategic Management Approach. Irwin - New York: McGraw-Hill. Afuah, A., Tucci, Ch.L. (2003). Biznes internetowy. Strategie i modele, Kraków: Oficyna Ekonomiczna Grupa Wolters Kluwer.

Ansoff, H.I. (1985). Zarzadzanie strategiczne. Warszawa: Polskie Wydawnictwo Ekonomiczne.

Bamford, Ch.E., West III, G.P. (2010). Strategic Management: Value Creation, Sustainability and Performance. Mason: South-Western Cengage Learning.

Brzóska, J. (2009). Model biznesowy - współczesna forma modelu organizacyjnego zarządzania przedsiębiorstwem. Organizacja i Zarządzanie. Kwartalnik Naukowy, 2(6), 5-23.

Casadesus-Masanell, R., Ricart, J.E. (2010). From strategy to business models and onto tactics. Long Range Planning, 43, 195-225.

Chandler, A.D. (1962). Strategy and Structure. Chapters in the History of the Industrial Enterprise. Cambridge: MIT Press.

Czaja, S., Tutaj, J., Becla, A., Andreeva, N. (2018). Uzdrowiska w zrównoważonym rozwoju regionu dolnoślaskiego. Wrocław: Wydawnictwo Uniwersytetu Ekonomicznego we Wrocławiu.

Das ganze Konzept Führung ist reif für eine Redefinition (2018, 1 września). Pozyskano z: http: www. wirtschaftsforum.de.

Doligalski, T. (red.). (2014). Modele biznesu w Internecie. Teoria i studia przypadków. Warszawa: Wydawnictwo Naukowe PWN.

Drzewiecki, J. (2013). Model biznesu jako narzędzie zarządzania strategicznego: zastosowanie, dylematy i wyzwania. Modele biznesowe. Przedsiębiorczość i Zarządzanie, t. XIV, 13(II), 67-76.

Duczkowska-Piasecka, M., Poniatowska-Jaksch, M., Duczkowska-Małysz, K. (2013). Model biznesu. Nowe myślenie strategiczne. Warszawa: Wydawnictwo Difin.

Firlej, K. (2013). Model biznesu w zarządzaniu przedsiębiorstwem spożywczym. Modele biznesowe. Przedsiębiorczość i Zarządzanie, t. XIV, 13(II), 27-40.

Gołębiowski, T., Dudzik, T.M., Lewandowska, M., Witek-Hajduk, M. (2008). Modele biznesu polskich przedsiębiorstw. Warszawa: SGH. 
Hołodnik, D., Perechuda, K. (2016). Przedsiębiorstwo nowej generacji. Annales Universitstis Mariae Curie-Stodowska,Sectio H, 2, 21-27.

Informacja na temat Programu Kuracjusz, Spółka Uzdrowisko Lądek-Długopole.

Iwasieczko, B. (2014). Modele biznesowe i ocena ich efektywności. Prace naukowe Uniwersytetu Ekonomicznego we Wrocławiu, 343, 152-176.

Jabłoński, M. (2013). Modele biznesu a kreacja wartości na rynku kapitałowym. Zeszyty Naukowe Uniwersytetu Szczecińskiego nr 761: Finanse, Rynki Finansowe, Ubezpieczenia, 60, 207-216.

Jabłoński, M. (2013). Cykl życia wartości przedsiębiorstw wobec kondycji modelu biznesu, Kwartalnik Nauk o Przedsiębiorstwie, 4, 57-63.

Jabłoński, M., Jabłoński, A. (2014). Kluczowe miary biznesowe w budowie wartości firmy. Pozyskano z: www.sbc. org.pl/Content/10328/jablonscy.pdf

Manterys, A. (1997). Wielość rzeczywistości w teoriach socjologicznych. Warszawa: PWN.

Michalak, J. (2012). Model biznesowy i jego wpływ na odwzorowanie sytuacji finansowej jednostki w systemie rachunkowości. Zeszyty Teoretyczne Rachunkowości, 66(122), 133-142.

Mikołajczyk, B., Krawczyk, M., Kurczewska, A. (2012). Ewolucja pomiaru innowacyjności w firmie. Acta Universitatis Lodziensis. Folia Oeconomica, 266, 251-261.

Motyka, S. (2013). Pomiar innowacyjności przedsiębiorstwa. Pozyskano z: http://www.ptzp.org.pl/files/ konferencje/ kzz/artyk_pdf_2011/075.pdf

Nęcki, Ł. (2013). Budowa nowoczesnego przedsiębiorstwa z wykorzystaniem modelu biznesowego canvas. Zeszyty Naukowe Politechniki Częstochowskiej Zarzadzanie, 11, 26-37.

Nowicka, K. (2012, 7 marca 2019) Cloud computing - nowy model biznesowy wykorzystujacy outsourcing IT poprzez Internet. Pozyskano z: www.praktycznateoria.pl/cloud-computing

Nowicka, K. (2013). Wartość w modelu cloud computing. Przedsiębiorstwo i Przyszłość, 2.

Obłój, K. (2013). Pasja i dyscyplina strategii. Jak $z$ marzeń i decyzji zbudować sukces firmy. Warszawa: Poltext.

Obłój, K. (1996). Strategia organizacji: budowanie trwałej przewagi konkurencyjnej. Warszawa: PWE.

Osterwalder, A., Pigneur, Y. (2012). Tworzenie modeli biznesowych. Podręcznik wizjonera. Gliwice: Wydawnictwo Helion.

Obłój, K. (2002). Tworzywo skutecznych strategii. Warszawa: PWE.

Pałka, D., Zaskórski, W., Zaskórski, P. (2013). Cloud computing jako środowisko integracji usług informatycznych. Zeszyty Naukowe Warszawskiej Wyższej Szkoly Informatyki, 9(7).

Rosińska-Bukowska, M. (2011) Modele biznesu sprzyjające kreacji wartości na przykładach wiodących przedsiębiorstw międzynarodowych. W: M. Jabłoński (red.), Zarządzanie wartością przedsiębiorstw. Finanse - Strategie - Kompetencje. Dąbrowa Górnicza: Wydawnictwo Naukowe Akademii WSB, 171-196.

Rutkowska-Gurak, A. (2010). W poszukiwaniu miar innowacyjności rozwoju. Acta Universitatis Lodziensis. Folia Oeconomica, 246, 65-77.

Skrzypek, E. (1999). Efektywność działań w TQM - koszty jakości. Problemy Jakości, 7, 5-13.

Stabryła, A. (2000). Zarzadzanie strategiczne w teorii i praktyce firmy. Warszawa - Kraków: Wydawnictwo Naukowe PWN.

Szymańska, E. (2010). Efektywność przedsiębiorstw - definiowanie i pomiar. Roczniki Nauk Rolniczych. Seria $G, 97(2)$.

Teece, D.J. (2010). Business models, business strategy and innovation. Long Range Planning, 43, 172-194.

Timmers, P. (1998). Business models for electronic commerce, Electronic Markets, 8(2), 3-8.

Weill, P., Vitale, M.R. (2001). Place to Space - Migrating to e-Business Models. Harvard Business School Publishing Corporation.

Wierzbiński, M. (2015). Model biznesowy a strategia i zarzadzanie strategiczne. Prace Naukowe Uniwersytetu Ekonomicznego we Wrocławiu, 395, 482-487.

Wierzbiński, M. (2017). Modelowanie finansowe w projektowaniu modelu biznesowego przedsiębiorstwa. Zarzadzanie i Finanse. Journal of Management and Finance, 15(2/2), 171-194. 
Ziora, L. (2012). Rola technologii cloud computing w zarządzaniu przedsiębiorstwem. Zeszyty Naukowe Uniwersytetu Szczecińskiego nr 702. Ekonomiczne Problemy Ustug, 87, 778-786.

Zott, Ch., Amit, R. (2010). Business model design: An activity system perspective. Long Range Planning, 43.

Jerzy Tutaj, dr, adiunkt, Wydział Informatyki i Zarządzania, Katedra Infrastruktury Zarządzania Politechniki Wrocławskiej. Absolwent Uniwersytetu Gdańskiego. W latach 1996-2004 pełnił funkcję dziekana Wydziału Nauk Społecznych. W latach 2004-2011 był Prezesem Zarządu Przedsiębiorstwa Zamek Książ. W latach 2011-2014 był członkiem zarządu województwa dolnośląskiego. Od blisko 30 lat jest nauczycielem akademickim. Jest autorem ponad 50 publikacji naukowych, w tym 7 książek z zakresu strategii rozwoju, innowacji, zarządzania, a także współautorem Strategii rozwoju województwa dolnoślaskiego 2020 oraz kilkunastu strategii rozwoju gmin i przedsiębiorstw. Jest członkiem Polskiego Towarzystwa Socjologicznego.

Jerzy Tutaj, PhD, Faculty of Computer Science and Management, Department of Infrastructure Management at the Wrocław University of Technology. A graduate of the University of Gdańsk. In the years 1996-2004 he was the dean of the Faculty of Social Sciences. In the years 2004-2011 he was the President of the Management Board of the Zamek Książ Enterprise. In the years 2011-2014 he was a member of the management board of the Dolnośląskie Voivodeship. An academic teacher with almost 30 years of experience. He is an author of over 50 publications, including seven books in the field of development strategy, innovation, management, as well as a co-author of the Development Strategy of the Dolnośląskie Voivodeship 2020 and several development strategies for municipalities and enterprises. He is a member of the Polish Sociological Association.

ORCID: 0000-0002-1764-5011

\section{Adres/Address:}

Politechnika Wrocławska

Wydział Informatyki i Zarządzania

Katedra Infrastruktury Zarządzania

Wybrzeże Wyspiańskiego 27

50-370 Wrocław, Polska 